\title{
PENGUATAN KETAHANAN PANGAN NASIONAL MELALUI STRATEGI PERBAIKAN EFISIENSI PEMASARAN HASIL PERTANIAN
}

\author{
Nur Baladina, Ratya Anindita, Budi Setiawan \\ Staf Pengajar Jurusan Sosial Ekonomi, Program Studi Agribisnis, \\ Fakultas Pertanian, Universitas Brawijaya, Malang \\ E-mail: baladina.fp@ub.ac.id
}

\begin{abstract}
The success of Indonesia to achieve food self-sufficient, mostly didn't support with the easiness to access the food. Therefore, it is need to strengthening national food security which concern to the accessibility aspect. One strategy that can be applied is by improving the marketing efficiency of agricultural product. Through this strategy, we will be enable to reduce the marketing margins, increased producer selling price and reduce the purchasing price in the level of consumer. Furthermore, the improving of marketing efficiency will support the availability and accessibility of food in the society. So, this study aims to determine the important of the strengthening efforts for national food security through marketing efficiency improvement strategy of agriculture commodity. NSSE data and Annual Input and Output table from year 2008 was used in this research and analyze by using Computable General Equilibrium (CGE) model. The empirical result shows that the improvement of marketing efficiency by $5-15 \%$ generally bring a positive effect to the national food security, based on the several indicators, such as the quantity of domestic output, exports, and imports. Therefore, it needs to arrange an action plan which is reference from the marketing efficiency improvements strategy. The concept of policies that can be set are as follows: (1) improving market information systems through the development of an auction market of agricultural products, (2) improving farmers performance to participate in marketing activities through strengthening farmers institutional, (3) improving transportation facilities, (4) apply of agricultural product hedging mechanism by Sistem Resi Gudang (SRG), (5) price stabilization of agricultural products, especially food crops, and (6) protection toward domestic agriculture production.
\end{abstract}

Keyword: food security, marketing efficiency improvement, Computable General Equilibrium

Abstrak: Keberhasilan Indonesia dalam kemandirian pangan pada level nasional,
tidak selalu diikuti dengan kemudahan dalam akses pangan. Oleh karena itu, perlu
adanya upaya memperkuat ketahanan pangan dari aspek kemudahan akses pangan.
Salah satu strategi yang dapat diterapkan adalah melalui perbaikan efisiensi pemasaran
hasil pertanian. Melalui kebijakan perbaikan efisiensi pemasaran, akan mampu
mengurangi marjin pemasaran, meningkatkan harga jual produsen dan mengurangi
harga beli konsumen. Oleh karena itu, penelitian ini bertujuan untuk mengkaji
pentingnya upaya penguatan ketahanan pangan nasional melalui strategi perbaikan
efisiensi pemasaran hasil pertanian. Dengan menggunakan model CGE/MPSGE
berdasarkan data SNSE Indonesia dan Tabel Input Output Indonesia 2008, dilakukan
analisis kuantitatif efek perbaikan efisiensi pemasaran hasil pertanian terhadap
penguatan ketahanan pangan nasional. Hasil analisis menunjukkan bahwa kebijakan
perbaikan efisiensi pemasaran hasil pertanian 5-15\% secara umum memberikan efek
yang positif terhadap ketahanan pangan nasional dilihat dari indikator kuantitas output
domestik, ekspor, dan impor. Oleh karena itu, perlu segera disusun rencana aksi dari 
strategi kebijakan perbaikan efisiensi pemasaran hasil pertanian. Konsep kebijakan yang dapat disusun antara lain: (1) perbaikan sistem informasi pasar melalui pengembangan pasar lelang produk pertanian,(2) peningkatan kinerja petani untuk ikut serta dalam kegiatan pemasaran melalui penguatan kelembagaan petani, (3) perbaikan sarana dan prasarana transportasi, (4) penerapan mekanisme lindung nilai (hedging) melalui Sistem Resi Gudang (RSG), (5) stabilisasi harga produk pertanian terutama tanaman pangan di tingkat produsen (petani), (6) perlindungan terhadap produk pertanian domestik dari serangan produk pertanian impor.

Kata kunci: ketahanan pangan, perbaikan efisiensi pemasaran, Computable General Equilibrium (CGE)

\section{PENDAHULUAN}

Ketahanan pangan terdiri dari empat sub sistem utama yaitu ketersediaan (food availability), akses pangan (food access), penyerapan pangan (food utilization), dan stabilitas pangan (food stability), sedangkan status gizi (nutritional status) merupakan outcome dari ketahanan pangan (Weingartner, 2004). Ketersediaan, akses, penyerapan, dan stabilitas pangan merupakan satu kesatuan sub sistem yang harus dipenuhi secara utuh. Jika salah satu subsistem tersebut tidak dipenuhi, maka suatu negara belum dapat dikatakan mempunyai ketahanan pangan yang baik. Seperti yang terjadi di Afrika pada pertengahan tahun 1980, ketika fokus pada peningkatan produksi untuk mencapai swasembada justru menimbulkan adanya krisis pangan pada masyarakat. Ada pula negara yang mampu melakukan swasembada produksi pangan pada level nasional, namun dapat dijumpai masyarakatnya yang rawan pangan karena ada hambatan akses dan distribusi pangan (Stevens et all., 2000). Oleh karena itu, ketersediaan pangan pada level nasional tidak secara otomatis menjamin ketahanan pangan pada level individu dan rumah tangga. (Borton dan Shoham, 1991). Walaupun pangan tersedia cukup di tingkat nasional dan regional, tetapi jika akses individu untuk memenuhi kebutuhan pangannya tidak merata, maka ketahanan pangan masih dikatakan rapuh.

Keberhasilan Indonesia dalam kemandirian pangan seperti komoditi beras tidak selalu diikuti dengan kemudahan dalam akses pangan. Oleh karena itu, fokus ketahanan pangan nasional yang menjadi prioritas saat ini diharapkan tidak hanya dari aspek ketersediaan pangan melalui usaha swasembada pangan saja, namun yang lebih penting adalah bagaimana mewujudkan ketahanan pangan dari aspek kemudahan akses pangan. Salah satu strategi yang dapat diterapkan adalah melalui perbaikan efisiensi pemasaran hasil pertanian.

Dalam pembangunan pertanian, perbaikan efisiensi pemasaran hasil pertanian memiliki peran yang sangat penting, yaitu (1) meningkatkan spesialisasi aktivitas dalam keunggulan komparatif sehingga suatu negara lebih mampu melakukan perdagangan; (2) meningkatkan efisiensi dan perdagangan sumberdaya alam; dan (3) kemajuan di bidang pemasaran akan mendorong pertumbuhan ekonomi (Smalley dan Ehui, 1995). Hayami (2001) juga menyatakan bahwa pasar yang efisien dan efisiensi pemasaran mempunyai implikasi penting dalam kebijaksanaan pembangunan ekonomi, khususnya pertanian. Dalam pasar yang efisien, diperlukan adanya intervensi pemerintah dengan cara membangun sistem informasi dan infrastuktur yang efisien melalui sistem pemasaran dari daerah perdesaan sampai ke konsumen sehingga informasi harga dan produk mampu diperoleh oleh produsen dan konsumen, yang pada akhirnya mampu mengurangi marjin pemasaran, meningkatkan harga jual produsen dan mengurangi harga beli konsumen.

Semakin kecilnya marjin pemasaran akan berdampak langsung dengan meningkatnya harga jual produsen yang disebut sebagai efek perbaikan efisiensi pemasaran (Mellor, 1967). Efek perbaikan efisiensi pemasaran secara tidak langsung juga akan menurunkan harga konsumen. Dengan demikian peningkatan efisiensi pemasaran akan menyebabkan turunnya harga eceran yang kemudian akan mendorong jumlah permintaan yang pada akhirnya akan menciptakan 
dorongan kenaikan harga di tingkat produsen. Pada saat yang sama, kenaikan harga ini akan memperbaiki efisiensi harga di tingkat pedagang perantara sehingga biaya produksi dapat dikurangi. Harga di tingkat konsumen akan mendorong konsumen untuk dapat membeli produk yang lebih banyak tergantung dari seberapa besar dorongan kenaikan jumlah permintaan terhadap kenaikan harga, dimana kenaikan tersebut tergantung dari jenis elastisitas atau responsiveness komoditi tersebut terhadap perubahan harga (Landes dan Burfisher, 2009).

Perbaikan efisiensi pemasaran dapat dilakukan melalui peningkatan kinerja petani untuk ikut dalam kegiatan pemasaran, perbaikan sistem informasi harga dan pasar, pembangunan pasar induk dan pasar lelang produk pertanian, serta perbaikan sarana prasarana transportasi. Dengan kebijakan perbaikan efisiensi pemasaran, diharapkan harga yang diterima petani semakin tinggi dan harga yang dibayar konsumen lebih rendah. Jika stabilitas harga terwujud baik bagi produsen maupun konsumen, lebih lanjut akan mendorong peningkatan konsumsi dan produksi hasil pertanian. Pada akhirnya perbaikan efisiensi pemasaran akan mewujudkan ketersediaan pangan dan perbaikan akses pangan masyarakat, yang selanjutnya akan terkait pula dengan peningkatan penyerapan pangan, sehingga ketahanan pangan nasional menjadi lebih baik/kuat. Oleh karena itu, tulisan ini bertujuan untuk mengkaji pentingnya upaya penguatan ketahanan pangan nasional melalui strategi perbaikan efisiensi pemasaran hasil pertanian.

\section{METODE PENELITIAN}

Selama ini keterbatasan informasi pentingnya kebijakan pemasaran di Indonesia adalah melihat bagaimana dampak perbaikan pemasaran terhadap perekonomian. Model untuk melihat dampak perbaikan pemasaran terhadap pertumbuhan ekonomi pertama kali dikembangkan oleh Arndt et al. (1999) melalui model CGE (Computable General Equilibrium) di Mozambique dan kemudian Landes dan Burfisher (2009) melihat yang lebih komprehensif efeknya terhadap perekonomian di India.
Pada dasarnya model CGE yang dikembangkan dalam penelitian ini adalah bagaimana mengintroduksi marjin pemasaran dalam model perekonomian sehingga perubahan aktivitas marjin pemasaran akan mempengaruhi aktivitas lain yaitu impor, ekspor dan pemasaran domestik yang selanjutnya akan mempengaruhi kinerja perekonomian sektoral dan ketahanan pangan. Untuk mencapai tujuan tersebut digunakan model CGE statis untuk Indonesia dengan asumsi constant return to scale sesuai yang dianjurkan oleh Soudolet and Janvry (1995) dan Lofgren et al. (2002). Model ini lebih sesuai untuk melihat efek dari kebijaksanaan. Data yang digunakan untuk analisis CGE adalah data Statistik Nasional Sosial Ekonomi (SNSE) Indonesia dan Tabel Input Output tahun 2008. Disagregasi dilakukan terhadap sektor pertanian tanaman pangan yang ditindaklanjuti dengan mengeliminasi elemen negatif dalam SNSE Indonesia. Setelah SNSE ini diseimbangkan, kegiatan selanjutnya adalah mapping SNSE, menyusun model data dan model statis CGE yang diselesaikan dengan GAMS/MPSGE. Model ini kemudian dikalibrasi dan divalidasi dengan menggunakan data SNSE Indonesia yang telah dimodifikasi untuk mendapatkan parameter penelitian. Untuk koefisien/ parameter lainnya seperti elastisitas Armington, elastisitas faktor produksi primer, dan elastisitas substitusi diperoleh dari berbagai sumber penelitian terdahulu.

Menurut Breisinger et al. (2009), SNSE adalah suatu kerangka data perekonomian terbuka yang komprehensif yang mewakili perekonomian suatu negara. Sementara Hosoe et al. (2010) menyatakan bahwa SNSE dituliskan dalam tabel bentuk matriks persegi dengan nama agen sebagai nama baris dan nama kolom. Penerimaan dalam SNSE menunjukkan aliran barang dan jasa dari agen dalam baris ke agen dalam kolom yang bersesuaian (counterpart). Hal yang berhubungan dengan pembayaran (atau aliran dana) dibuat dengan arah yang berlawanan. Dengan menggunakan GAM/MPSGE, kalibrasi dapat dilakukan secara bersamaan (Markusen, 2005). 


\section{HASIL DAN PEMBAHASAN}

\section{Kontribusi Sektor Pertanian Terhadap GDP}

Salah satu peran penting sektor pertanian dalam kerangka keseimbangan umum (perekonomian Indonesia) adalah kontribusinya terhadap pembentukan gross domestic product (GDP) Indonesia. Berdasarkan atas pengertian pertanian dalam arti sempit, sektor pertanian dalam tulisan ini dibedakan atas: (1) pertanian tanaman pangan yang didisagregasi menjadi sektor tanaman padi, kacang-kacangan, jagung, umbi-umbian, sayur dan buah, bahan makanan lainnya, (2) pertanian tanaman lainnya. Menurut penerimaan produksi atas dasar harga pembeli, sektor pertanian memberikan kontribusi sebesar 6,45\% (669.620,1 miliar rupiah) terhadap GDP Indonesia. Adapun total GDP Indonesia pada tahun 2008 tercatat 10.374.197 miliar rupiah. Secara rinci seperti yang tercantum di Tabel 1, sektor tanaman padi, sektor pertanian tanaman lainnya, serta sektor sayur dan buah merupakan sektor pertanian yang mempunyai kontribusi tertinggi terhadap perekonomian Indonesia. Kontribusi masing-masing sektor ini tercatat sebesar $2,06 \% ; 1,95 \%$ dan $1,14 \%$.

Meskipun kontribusi sektor pertanian terhadap GDP Indonesia ini relatif kecil, keterkaitannya dengan sektor-sektor lainnya, baik keterkaitan ke belakang (backward linkage) maupun keterkaitan ke depan (forward linkage) menunjukkan pentingnya sektor pertanian. Oleh karena itu, berbagai kebijakan dalam rangka mengembangkan dan memperbaiki kinerja di sektor pertanian, termasuk perbaikan efisiensi pemasaran produk-produk pertanian akan mempunyai efek terhadap sektor-sektor lainnya yang terkait dengan sektor pertanian, misalnya industri makanan dan minuman, industri pupuk dan pestisida, dan diantara sub sektor pertanian itu sendiri, sehingga pada akhirnya akan memperkuat ketahanan pangan nasional.

\section{Efek Perbaikan Efisiensi Pemasaran Terhadap Penguatan Ketahanan Pangan Nasional}

Untuk mempertajam analisis, dalam kajian efek perbaikan efisiensi pemasaran terhadap penguatan ketahanan pangan nasional, dilakukan beberapa simulasi meliputi: (a) perbaikan efisiensi pemasaran sebesar 5\%, (b) perbaikan efisiensi pemasaran sebesar $8 \%$, (c) perbaikan efisiensi pemasaran sebesar $10 \%$, dan (d) perbaikan efisiensi pemasaran sebesar $15 \%$. Berikut ini dijelaskan bagaimana efek perbaikan efisiensi pemasaran hasil pertanian terhadap ketahanan pangan nasional dilihat dari indikator kuantitas output domestik, ekspor, dan impor.

\section{Efek Terhadap Output Domestik}

Tabel 2 menunjukkan bahwa kebijakan perbaikan efisiensi pemasaran hasil pertanian $5-15 \%$ memberikan efek positif terhadap peningkatan output domestik hampir di semua sektor, kecuali sektor industri pupuk dan pestisida yang turun $7,9-8,4 \%$ serta kacangkacangan yang konstan tidak mengalami peningkatan. Hasil ini sesuai dengan teori Mellor (1967) serta Smalley dan Ehui (1995),

Tabel 1. Kontribusi Sektor Pertanian terhadap GDP Indonesia Tahun 2008

\begin{tabular}{llrr}
\hline \multirow{2}{*}{ No. } & \multicolumn{1}{c}{ Sektor } & \multicolumn{2}{c}{ Kontribusi terhadap GDP Indonesia } \\
\cline { 3 - 4 } & & Nilai (miliar rupiah) & Persen (\%) \\
\hline 1. & Padi & $213.755,70$ & 2,06 \\
2. & Kacang-kacangan & $15.640,91$ & 0,15 \\
3. & Jagung & $96.014,30$ & 0,93 \\
4. & Umbi-umbian & $21.844,49$ & 0,21 \\
5. & Sayur dan Buah & $118.457,10$ & 1,14 \\
6. & Bahan Makanan Lainnya & $1.656,52$ & 0,02 \\
7. & Pertanian Tanaman Lainnya & $202.251,10$ & 1,95 \\
\hline
\end{tabular}

Sumber : Data Sekunder Diolah, 2012 
Nur Baladina, Ratya Anindita, Budi Setiawan : Penguatan ketahanan pangan nasional ...

Tabel 2. Perubahan Kuantitas Output Domestik

\begin{tabular}{|c|c|c|c|c|c|}
\hline \multirow[b]{2}{*}{ Sektor } & \multirow{2}{*}{$\begin{array}{c}\text { Baseline } \\
\text { (Triliun Rp) }\end{array}$} & \multicolumn{4}{|c|}{ Efek Perbaikan Efisiensi Pemasaran (\%) } \\
\hline & & $5 \%$ & $8 \%$ & $10 \%$ & $15 \%$ \\
\hline Padi & 216 & 113,89 & 159,72 & 159,72 & 159,72 \\
\hline Kacang-kacangan & 38 & 0 & 0 & 0 & 0 \\
\hline Jagung & 109 & 38,53 & 47,71 & 47,71 & 47,71 \\
\hline Umbi-umbian & 24 & 70,83 & 66,67 & 66,67 & 66,67 \\
\hline Sayur dan Buah & 513 & 28,27 & 33,72 & 33,53 & 33,53 \\
\hline Bahan makanan lain & 2 & 200 & 100 & 100 & 100 \\
\hline Pertanian Tanaman lain & 1.303 & 9,67 & 13,43 & 13,43 & 13,43 \\
\hline Peternakan & 531 & 57,25 & 74,2 & 74,2 & 74,58 \\
\hline Kehutanan dan perburuan & 133 & 1,5 & 2,26 & 2,26 & 2,26 \\
\hline Perikanan & 338 & 120,12 & 122,78 & 123,08 & 123,08 \\
\hline Industri Makanan dan Minuman & 6.315 & 12,16 & 17,34 & 17,56 & 17,66 \\
\hline Industri Pupuk dan Pestisida & 215 & $-7,91$ & $-8,37$ & $-8,37$ & $-8,37$ \\
\hline Industri lainnya & 28.113 & 32,63 & 55,02 & 55,02 & 54,99 \\
\hline Jasa & 5538 & 7,75 & 13,87 & 13,87 & 13,87 \\
\hline
\end{tabular}

Sumber : Hasil Analisis Simulasi, 2012

bahwa perbaikan efisiensi pemasaran akan mendorong pertumbuhan ekonomi dengan berkurangnya marjin pemasaran yang pada akhirnya mendorong kenaikan harga jual produsen dan lebih lanjut akan meningkatkan produksi output. Untuk tanaman pangan, padi mengalami peningkatan kuantitas output pertanian tanaman pangan terbesar (113-159\%) akibat perbaikan efisiensi pemasaran, sehingga diharapkan dapat mendukung program swasembada beras yang dicanangkan pemerintah Indonesia 2014.

Sementara itu, peningkatan kuantitas output pertanian seperti sayur dan buah sebagai sumber vitamin dan mineral (28-33\%), bahan makanan lain (100-200\%), pertanian tanaman lain (9-13\%), peternakan sebagai sumber protein hewani $(57-74 \%)$, kehutanan dan perburuan (1-2\%), serta perikanan sebagai sumber protein dan omega 3 (120-123\%) mengindikasikan bahwa ketersediaan pangan (food availability) dan keanekaragaman pangan (food diversification) yang menurut Weingartner (2004) merupakan salah satu sub sistem utama sistem ketahanan pangan (food security) semakin kuat tercapai di Indonesia. Sedangkan meningkatnya kuantitas output industri makanan dan minuman (12-17\%) diduga sebagai dampak ikutan meningkatnya kuantitas output pertanian tanaman pangan dan bahan makanan lain, seperti sayur dan buah, peternakan, kehutanan dan perburuan, serta perikanan yang pada akhirnya juga meningkatkan output industri makanan dan minuman sebagai industri hilir dari produkproduk pertanian segar tersebut.

Namun meningkatnya output pertanian tanaman pangan, sayur dan buah, serta pertanian tanaman lain tidak didukung oleh industri pupuk dan pestisida. Kondisi ini menunjukkan bahwa program "Go Organik" yang dicanangkan pemerintah, berhasil diterapkan di masyarakat. Masyarakat domestik secara sadar telah mengurangi penggunaan pupuk dan pestisida kimia, kemudian menggantinya dengan pupuk dan pestisida organik yang lebih ramah lingkungan, seperti penggunaan pestisida alami dari daun nimba atau penggunaan pupuk organik dari kotoran ayam, kambing, dan sapi, atau air seni kelinci. Asumsinya jika output sektor peternakan meningkat, maka hasil sampingan berupa air seni dan kotoran ternak sebagai bahan baku pupuk organik juga meningkat. Berkurangnya penggunaan pupuk dan pestisida kimia di tingkat petani diduga menjadi penyebab industri pupuk dan pestisida mengurangi produksinya. 
Kuantitas output kacang-kacangan yang konstan tidak mengalami peningkatan diduga karena kacang-kacangan kalah bersaing dalam hal penggunaan lahan dibandingkan tanaman pangan, sayur dan buah, serta pertanian tanaman lain. Komoditi ini umumnya dibudidayakan di lahan sawah dan lahan kering yang juga merupakan areal tanaman pangan, sayur dan buah, serta pertanian tanaman lain, sehingga ketika terjadi perbaikan efisiensi pemasaran yang pada akhirnya mendorong kenaikan harga jual produsen, tidak serta-merta meningkatkan kuantitas output sektor kacangkacangan.

Perbaikan efisiensi pemasaran ternyata juga mampu mendorong kenaikan kuantitas output domestik sektor industri lainnya (32$55 \%)$ dan sektor jasa (7-14\%). Informasi ini mendukung pernyataan bahwa berbagai kebijakan dalam rangka mengembangkan dan memperbaiki kinerja di sektor pertanian, termasuk perbaikan efisiensi pemasaran produk-produk pertanian, akan mempunyai efek positif terhadap kinerja sektor-sektor lainnya yang terkait ke belakang (backward linkage) maupun ke depan (forward linkage) dengan sektor pertanian.

\section{Efek Terhadap Kuantitas Ekspor}

Berdasarkan hasil simulasi yang tersaji pada Tabel 3, kebijakan perbaikan efisiensi pemasaran hasil pertanian $5-15 \%$ memberikan dampak positif terhadap peningkatan kuantitas ekspor hampir di semua sektor, kecuali sektor pertanian tanaman pangan pada komoditas padi dan sektor pertanian tanaman lain yang mengalami penurunan, serta sektor industri pupuk dan pestisida yang konstan tidak mengalami perubahan. Komoditas padi dan sektor pertanian lain saat ini tidak diekspor karena masih belum mampu memenuhi kebutuhan domestik. Penurunan kuantitas ekspor ini diduga karena pertumbuhan penduduk di Indonesia yang pesat, tingginya permintaan penduduk domestik terhadap komoditas padi (beras), serta meningkatnya daya beli konsumen dalam negeri sebagai dampak ikutan dari perbaikan efisiensi pemasaran, sehingga meskipun kuantitas output domestik komoditas padi dan sektor pertanian tanaman lain meningkat, tetap terjual habis di pasar domestik.
Sedangkan kuantitas ekspor sektor industri pupuk dan pestisida konstan tidak mengalami perubahan dari baseline 2 trilyun rupiah, hal ini diduga karena masih belum mampu memenuhi kebutuhan domestik. Apalagi output domestik industri pupuk dan pestisida justru turun 7,9-8,4\% dari baseline 215 trilyun rupiah ketika dilakukan perbaikan efisiensi pemasaran 5-15\%, sehingga output domestik sektor industri pupuk dan pestisida telah terjual habis di pasar domestik tanpa perlu diekspor.

Untuk pertanian tanaman pangan, kebijakan perbaikan efisiensi pemasaran hasil pertanian $5-15 \%$ berdampak positif terhadap meningkatnya kuantitas ekspor yaitu 126-143\% untuk kacang-kacangan, $186-197 \%$ untuk jagung, dan $1.287 \%$ untuk umbi-umbian. Teori Mellor (1967) serta Smalley dan Ehui (1995) menyatakan bahwa perbaikan efisiensi pemasaran mendorong kenaikan harga jual di tingkat produsen sehingga produsen merespon dengan meningkatkan produksi outputnya. Namun di sisi lain penduduk domestik masih memiliki ketergantungan tinggi terhadap konsumsi padi (beras), sehingga peningkatan kuantitas output pertanian tanaman pangan selain padi (beras) tidak terserap habis di pasar domestik dan harus dijual/ekspor ke pasar luar negeri. Sementara itu, meningkatnya kuantitas ekspor beberapa sektor seperti sayur dan buah sebagai sumber vitamin dan mineral (120$130 \%)$, bahan makanan lain (298-399\%), peternakan sebagai sumber protein hewani $(102,56 \%)$, kehutanan dan perburuan (5-6,7\%), perikanan sebagai sumber protein dan omega 3 $(175-200 \%)$, serta industri makanan dan minuman (20-24\%) diduga karena sebagian dari output domestik bahan pangan ini tidak terjual habis di pasar domestik sehingga harus dijual (diekspor) ke pasar luar negeri. Melemahnya daya beli konsumen dalam negeri menyebabkan konsumen mengurangi konsumsi atas barang-barang yang harganya naik dan akibatnya kuantitas output yang tidak terjual di pasar domestik menjadi lebih besar. Informasi ini menunjukkan bahwa ketahanan pangan (food security) nasional masih rapuh karena ketersediaan pangan bergizi (food availability) dan keanekaragaman pangan (food diversification) dalam bentuk peningkatan kuantitas output domestik seperti sayur dan buah, bahan makanan lain, peternakan, 
Nur Baladina, Ratya Anindita, Budi Setiawan : Penguatan ketahanan pangan nasional ...

Tabel 3. Perubahan Kuantitas Ekspor

\begin{tabular}{|c|c|c|c|c|c|}
\hline \multirow{2}{*}{ Sektor } & \multirow{2}{*}{$\begin{array}{l}\text { Baseline (Triliun } \\
\text { Rp) }\end{array}$} & \multicolumn{4}{|c|}{ Efek Perbaikan Efisiensi Pemasaran (\%) } \\
\hline & & $5 \%$ & $8 \%$ & $10 \%$ & $15 \%$ \\
\hline Padi & 0,001 & -100 & -100 & -100 & -100 \\
\hline Kacang-kacangan & 0,043 & 125,93 & 142,04 & 143,04 & 143,04 \\
\hline Jagung & 0,201 & 185,62 & 196,83 & 197,4 & 197,51 \\
\hline Umbi-umbian & 0,072 & $1.286,96$ & $1.286,96$ & $1.286,96$ & $1.286,96$ \\
\hline Sayur dan Buah & 0,382 & 120,44 & 129,94 & 130,18 & 130,18 \\
\hline Bahan makanan lain & 0,053 & 298,34 & 399,48 & 418,43 & 418,97 \\
\hline Pertanian Tanaman lain & 13 & $-53,85$ & $-61,54$ & $-61,54$ & $-61,54$ \\
\hline Peternakan & 0,494 & 102,56 & 102,56 & 102,56 & 102,56 \\
\hline Kehutanan dan perburuan & 0,474 & 6,67 & 5,13 & 5,24 & 5,24 \\
\hline Perikanan & 4 & 175 & 200 & 200 & 200 \\
\hline Industri Makanan dan Minuman & 1.145 & 20,7 & 24,37 & 24,37 & 24,37 \\
\hline Industri Pupuk dan Pestisida & 2 & 0 & 0 & 0 & 0 \\
\hline Industri lainnya & 4.346 & 72,5 & 96,225 & 96,23 & 96,23 \\
\hline Jasa & 55,929 & 56,2 & 67 & 67 & 67 \\
\hline
\end{tabular}

Sumber : Hasil Analisis Simulasi, 2012

kehutanan dan perburuan, perikanan, serta industri makanan dan minuman tidak diikuti dengan optimalnya akses (food access) dan penyerapan pangan (food utilization).

Perbaikan efisiensi pemasaran sebesar 5$15 \%$ juga mampu mendorong kenaikan kuantitas ekspor sektor industri lainnya (7296\%) dan sektor jasa (56-67\%). Informasi ini menunjukkan bahwa perbaikan efisiensi pemasaran mampu menurunkan harga eceran konsumen yang selanjutnya akan mendorong meningkatnya jumlah permintaan ekspor dan pada akhirnya akan menciptakan dorongan kenaikan harga ekspor di tingkat produsen. Produsen selanjutnya merespon situasi ini dengan meningkatkan kuantitas penawaran ekspor. Ini berarti perbaikan efisiensi pemasaran dapat meningkatkan keunggulan komparatif sehingga Indonesia mampu bersaing lebih baik di pasar dunia.

\section{Efek Terhadap Kuantitas Impor}

Hasil simulasi yang tersaji pada Tabel 4 menyatakan bahwa kebijakan perbaikan efisiensi pemasaran hasil pertanian 5-15\% berpengaruh terhadap peningkatan kuantitas impor hampir di semua sektor, kecuali sektor pertanian tanaman pangan jagung, umbiumbian, kehutanan dan perburuan, perikanan, serta industri pupuk dan pestisida. Meskipun tidak meningkat, impor jagung yang tetap dilakukan pada baseline 1 trilyun rupiah serta impor sektor industri pupuk dan pestisida pada baseline 100 trilyun rupiah menunjukkan bahwa produksi jagung, pupuk dan pestisida domestik belum mampu memenuhi kebutuhan dalam negeri. Sedangkan tanaman pangan umbi-umbian, sektor kehutanan dan perburuan, serta sektor perikanan mengalami penurunan kuantitas impor sebesar 4,9-21,2\% disebabkan karena kuantitas output domestik sektor tersebut telah mampu memenuhi sebagian besar kebutuhan domestik.

Untuk tanaman pangan, perbaikan efisiensi pemasaran hasil pertanian 5-15\% akan meningkatkan kuantitas impor padi $(11,9 \%)$ dan kacang-kacangan (3,4-6,9\%). Kuantitas impor sektor padi mengalami peningkatan karena digunakan untuk memenuhi kebutuhan domestik akan padi (beras) yang masih defisit. Sedangkan peningkatan kuantitas impor kacang-kacangan diduga disebabkan karena terdapat beberapa kelas konsumen domestik yang menginginkan jenis kacang berkualitas tinggi dengan harga bersaing, sehingga menyebabkan kuantitas impornya mengalami sedikit peningkatan walaupun di sisi lain kuantitas output domestik kacang-kacangan tetap tidak berubah dari base line 38 trilyun rupiah dan kuantitas ekspornya mengalami 
Nur Baladina, Ratya Anindita, Budi Setiawan : Penguatan ketahanan pangan nasional ...

Tabel 4. Perubahan Kuantitas Impor

\begin{tabular}{|c|c|c|c|c|c|}
\hline \multirow{2}{*}{ Sektor } & \multirow{2}{*}{$\begin{array}{c}\text { Baseline } \\
\text { (Triliun Rp) }\end{array}$} & \multicolumn{4}{|c|}{ Efek Perbaikan Efisiensi Pemasaran (\%) } \\
\hline & & $5 \%$ & $8 \%$ & $10 \%$ & $15 \%$ \\
\hline Padi & 0,018 & 11,91 & 11,91 & 11,91 & 11,91 \\
\hline Kacang-kacangan & 29 & 3,45 & 6,9 & 6,9 & 6,9 \\
\hline Jagung & 1 & 0 & 0 & 0 & 0 \\
\hline Umbi-umbian & 0,191 & $-15,17$ & $-21,2$ & $-21,2$ & $-21,2$ \\
\hline Sayur dan Buah & 14 & 7,14 & 14,29 & 14,29 & 14,29 \\
\hline Bahan makanan lain & 26 & 261,54 & 103,85 & 107,69 & 107,69 \\
\hline Pertanian Tanaman lain & 54 & 68,52 & 100 & 100 & 100 \\
\hline Peternakan & 8 & 62,5 & 100 & 100 & 100 \\
\hline Kehutanan dan perburuan & 0,821 & $-4,86$ & $-5,98$ & $-5,98$ & $-5,98$ \\
\hline Perikanan & 0,33 & $-11,37$ & $-16,75$ & $-16,75$ & $-16,82$ \\
\hline Industri Makanan dan Minuman & 173 & 43,35 & 51,45 & 52,02 & 52,02 \\
\hline Industri Pupuk dan Pestisida & 100 & 0 & 0 & 0 & 0 \\
\hline Industri lainnya & 7.501 & 13,36 & 22,19 & 22,19 & 22,19 \\
\hline Jasa & 145 & 21,12 & 32,92 & 32,92 & 32,92 \\
\hline
\end{tabular}

peningkatan yang signifikan (125,93-143,04\%) dari base line 43 milyar rupiah.

Perbaikan efisiensi pemasaran hasil pertanian 5-15\% juga akan meningkatkan kuantitas impor beberapa sektor, antara lain pertanian sayur dan buah (7-14\%), bahan makanan lain (104-261\%), pertanian tanaman lain $(68-100 \%)$, peternakan $(62-100 \%)$, industri makanan dan minuman (43-52\%), industri lainnya (13-22\%), serta jasa (21-33\%). Selain untuk memenuhi kebutuhan domestik, meningkatnya impor dapat disebabkan karena daya saing komoditas domestik yang rendah. Hal ini ditandai dengan harga komoditas domestik yang relatif lebih tinggi dibandingkan harga komoditas impor, atau kualitas komoditas domestik yang relatif lebih rendah dibandingkan kualitas komoditas impor. Namun harga komoditas domestik yang lebih tinggi dalam jangka panjang juga dapat mendorong produsen dalam negeri untuk meningkatkan outputnya sehingga kuantitas impor akan turun.

\section{Rencana Aksi Strategi Kebijakan Perbaikan Efisensi Pemasaran Hasil Pertanian yang Mendukung Ketahanan Pangan Nasional}

Dari hasil analisis, diketahui bahwa kebijakan perbaikan efisiensi pemasaran hasil pertanian secara umum berdampak positif terhadap ketahanan pangan dilihat dari indikator kuantitas output domestik, ekspor, dan impor. Oleh karena itu, pemerintah perlu segera menyusun rencana aksi (regulasi) untuk mengefektifkan strategi kebijakan perbaikan efisiensi pemasaran hasil pertanian agar dapat diaplikasikan untuk mendukung tercapainya program ketahanan pangan di Indonesia, antara lain:

1. Pengembangan pasar lelang produk pertanian/agribisnis. Keberadaan pasar lelang pertanian di lokasi yang tepat, diharapkan akan memperlancar pemasaran produk pertanian dan memberi manfaat bagi seluruh pelaku pemasaran. Petani akan menikmati harga yang tinggi sesuai dengan kualitas poduk yang dihasilkan, sedangkan produk yang bermutu rendah akan dihargai lebih rendah. Dengan demikian petani mendapatkan keuntungan dari setiap peningkatan mutu yang diberikan terhadap produknya. Pasar lelang komoditas pertanian juga akan menjadi fasilitator dan intermediasi antar petani (gapoktan) dan pembeli, baik pedagang pengencer, pengumpul, pedagang besar dan kosumen akhir dengan jaringan pemasaran yang lebih pendek dan trasparan.

2. Meningkatkan kinerja petani untuk ikut serta dalam kegiatan pemasaran melalui 
penguatan kelembagaan petani (gapoktan) di pedesaan. Peluang pasar yang ada selama ini belum dapat dinikmati petani secara utuh karena para petani/produsen enggan untuk ikut serta dalam aktivitas pemasaran dan nilai tambah (pengolahan pasca panen). Padahal menurut Downey dan Erickson (2002), keuntungan dari usaha tani/ budidaya hanya $30 \%$ saja, sedangkan $70 \%$ nya berada pada sektor hilir (pengolahan dan pemasaran). Petani juga cenderung bergerak sendiri-sendiri dalam memasarkan produknya, sementara para pedagang cenderung berkolusi, sehingga karena informasi pasar yang tidak seimbang menyebabkan daya tawar dan harga jual petani rendah. Dengan memasarkan produk secara bersama melalui kelembagaan petani (gapoktan), diharapkan dapat meningkatkan efisiensi dan efektifitas distribusi produk pertanian, sehingga pendapatan dan kesejahteraan petani juga meningkat.

3. Perbaikan sarana dan prasarana transportasi, karena salah satu permasalahan dalam pemasaran hasil pertanian adalah lokasi produksi yang berpencar-pencar dan terkadang terpisah jauh dari lokasi konsumen, sehingga produk pertanian harus dikumpulkan dalam jumlah tertentu agar transportasi atau penyimpanannya dapat lebih efisien. Namun upaya tersebut seringkali terhambat dengan sulitnya transportasi dan lemahnya infrastruktur yang menghubungkan antara produsen dengan pasar dan konsumen. Dengan adanya perbaikan sarana dan prasarana tranportasi yang menghubungkan antara daerah sentra produksi dengan sentra konsumen, diharapkan proses pemasaran hasil pertanian menjadi lebih efisien.

4. Penerapan Sistem Resi Gudang (RSG).

Komoditas pangan dan pertanian mengandung risiko usaha seperti faktor musim, jeda waktu (time-lag) antara mulai tanam dengan waktu panen, serta perbedaan produktivitas dan kualitas produk yang cukup mencolok. Oleh karena itu, sangat perlu dilakukan upaya mengurangi resiko usaha dan ketidakpastian pasar melalui mekanisme lindung nilai (hedging) pada Sistem Resi Gudang (RSG). SRG telah diterapkan sebagai pembiayaan alternatif di Indonesia atau warehouse receipt di sentra- sentra produksi untuk komoditi gabah, beras, jagung, kopi, kakao, lada, karet, dan rumput laut melalui UU No. 9 tahun 2006 yang kemudian direvisi pada tahun 2011. Dengan model SRG, petani dapat menyimpan produknya ke pengelola gudang yang ditandai dengan bukti penyimpanan dalam bentuk resi gudang. Resi ini selanjutnya dapat dijadikan jaminan untuk mendapatkan pembiayaan dari lembaga keuangan. Pada masa-masa tertentu bila harga gabah sudah membaik, produk dapat dipasarkan dengan sistem lelang untuk mendapatkan harga tertinggi. Melalui diterapkannya sistem resi gudang, diharapkan akan dapat meningkatkan harga jual produk pertanian serta menjamin ketersediaan produk bagi konsumen. Sistem ini juga akan mendorong petani untuk berusaha secara berkelompok sehingga akan meningkatkan efisisensi dan posisi tawar petani, serta menghasilkan produk pertanian dengan mutu yang baik sesuai dengan standar yang telah ditetapkan.

5. Kebijakan stabilisasi harga produk pertanian terutama tanaman pangan di tingkat produsen (petani) dan konsumen. Langkah konkrit dari intervensi pemerintah ini adalah dengan melindungi produsen dari anjloknya harga produk pertanian pada musim panen serta melindungi konsumen dari melambungnya harga kebutuhan pokok pada musim tanam atau musim paceklik melalui kebijakan penentuan harga eceran tertinggi (HET). Melalui kebijakan ini, produsen (petani) dapat berharap harga jual produksinya dibeli dengan harga yang tinggi, sedangkan konsumen dapat membeli kebutuhan pokok dengan harga terjangkau.

6. Perlindungan terhadap produk-produk pertanian domestik dari serangan produk pertanian impor. Kebijakan ini dapat berupa pemberlakuan bea masuk (tarif impor) bagi produk-produk dari negara lain yang masuk ke dalam negeri. Dengan adanya tarif impor, maka akan meningkatkan biaya pemasaran dan harga produk impor menjadi lebih tinggi sehingga produk dalam negeri mampu bersaing dengan produk impor tersebut. Kebijakan lainnya yang dapat dikembangkan adalah dengan kebijakan non tarif seperti penetapan kuota impor, pencantuman label halal, dan safety produk. 


\section{KESIMPULAN DAN IMPLIKASI KEBIJAKAN}

1. Kebijakan perbaikan efisiensi pemasaran hasil pertanian 5-15\% memberikan efek positif terhadap peningkatan output domestik hampir di semua sektor, kecuali sektor industri pupuk dan pestisida yang turun $7,9-8,4 \%$ serta kacang-kacangan yang konstan tidak mengalami peningkatan. Untuk tanaman pangan, padi mengalami peningkatan kuantitas output terbesar (113$159 \%$ akibat perbaikan efisiensi pemasaran, sehingga diharapkan dapat mendukung program swasembada beras yang dicanangkan pemerintah Indonesia 2014.

2. Kebijakan perbaikan efisiensi pemasaran hasil pertanian $5-15 \%$ berpengaruh positif terhadap peningkatan kuantitas ekspor hampir di semua sektor (5-1.287\%), kecuali sektor pertanian tanaman pangan pada komoditas padi dan sektor pertanian tanaman lain yang mengalami penurunan, serta sektor industri pupuk dan pestisida yang konstan tidak mengalami perubahan.

3. Kebijakan perbaikan efisiensi pemasaran hasil pertanian $5-15 \%$ berpengaruh terhadap peningkatan kuantitas impor hampir di semua sektor, kecuali pada tanaman pangan umbi-umbian, sektor perikanan, kehutanan dan perburuan yang mengalami penurunan 4,9-21,2\%, serta sektor pertanian tanaman pangan jagung dan industri pupuk dan pestisida yang konstan tidak mengalami perubahan.

4. Kebijakan perbaikan efisiensi pemasaran juga mampu mendorong kenaikan kuantitas output domestik dan kuantitas ekspor sektor industri lainnya di luar sektor pertanian dan sektor jasa. Ini berarti berbagai kebijakan dalam rangka mengembangkan dan memperbaiki kinerja di sektor pertanian, termasuk perbaikan efisiensi pemasaran produk-produk pertanian, akan mempunyai efek positif terhadap kinerja sektor-sektor lainnya yang terkait ke belakang (backward linkage) maupun ke depan (forward linkage) dengan sektor pertanian.

5. Kebijakan perbaikan efisiensi pemasaran hasil pertanian secara umum memberikan efek yang positif terhadap ketahanan pangan nasional dilihat dari indikator kuantitas output domestik, ekspor, dan impor. Oleh karena itu, perlu segera disusun rencana aksi dari strategi kebijakan perbaikan efisiensi pemasaran hasil pertanian agar dapat diaplikasikan untuk memperkuat ketahanan pangan nasional, antara lain: (a) Perbaikan sistem informasi harga dan pasar dengan mengembangkan Pasar Lelang produk pertanian (agribisnis); (b) Peningkatan kinerja petani dalam pemasaran; (c) Penguatan kelembagaan petani (gapoktan); (d) Perbaikan sarana dan prasarana transportasi; (e) Penerapan Sistem Resi Gudang (SRG); (f) Stabilisasi harga produk pertanian melalui harga dasar dan harga atap; (g) Perlindungan produk pertanian domestik dari serangan produk impor.

\section{DAFTAR PUSTAKA}

Anindita, Ratya. 2010. Dampak Efisiensi Pemasaran Hasil Pertanian Terhadap Perekonomian Indonesia. Pidato Pengukuhan Jabatan Guru Besar dalam Bidang Ilmu Pemasaran Hasil Pertanian pada Fakultas Pertanian Universitas Brawijaya. BAPSI UB.

Arndt, Channing; Henning Tarp Jensen; Sherman Robinson and Finn Tarp. 1999. Marketing Margins and Agricultural Technology in Mozambique. Trade and Macroeconomics Division. International Food Policy Research Institute. Washington D.C, USA

Badan Pusat Statistik. 2010. Tabel Sistem Neraca Sosial Ekonomi Indonesia tahun 2008. Jakarta: BPS.

2009. Tabel Input Output Indonesia Updating 2008. Jakarta: BPS.

Borton, J. And J. Shoham, 1991. Mapping Vulnerability to Food Insecurity: Tentative Guidelines for WFP Offices, Mimeo. Study Commisioned by the World Food Programme. London: Relief and Development Institute.

Breisinger, C., Marcelle Thomas, dan James Thurlow. 2009. Social Accounting Matrices and Multiplier Analysis: An Introduction with Exercises. Food 
Nur Baladina, Ratya Anindita, Budi Setiawan : Penguatan ketahanan pangan nasional ...

Security in Practice Series. Washington D.C.: The International Food Policy Research Institute (IFPRI).

Hayami, Yujiro. 2001. Development Economics: From the Poverty to the Wealth of Nations. Oxford University Press. Second Edition.

Hosoe, N., Kenji Gasawa dan Hideo Hashimoto. 2010. Textbook of Computable General Equilibrium Modelling: Programming and Simulations. New York: Palgrave Macmillan.

Landes dan Burfisher, 2009. Growth and Equity Effects of Agricultural Marketing Efficiency in India. United States Department of Agriculture. Economic Research Report No.88.

Lofgren,H., Rebecca Lee Harris, Sherman Robinson. 2002. A Standard Computable General Equilibrium (CGE) Model in GAMS. Microcomputers in Policy Research International Food Policy Research Institute. Washington DC.
Markusen, J R. 2005. Introduction to GAMS for Economic Euilibriums Problems. University of Colorado, Boulder, version July 4, 2005.

Mellor, JW. 1967. Toward a Theory of Agricultural Development in Agriculture Development and Economic Growth. Edited by HS Southworth dan BF Johnston. Cornell University Press.

Smalley, EM dan Ehui,S . 1995. Livestock Policy Analysis. International Livestock Research Institute. Training Manual 2. ILRI, Nairobi, Kenya. pp. 264.

Soudolet, Elizabeth and Alan de Janvry. 1995. Quantitave Development Policy Analysis. The Jhon Hopkins University Press

Weingartner, L. 2004. The Concept of Food and Nutrition Security in Klaus Klennert (ed). Achieving Food and Nutrition Security: Actions to Meet the Global Challenge. Bonn, Germany. 